\title{
Microbial water quality of treated water and raw water sources in the Harare area, Zimbabwe
}

\author{
Tatenda G Chirenda**, Sunitha C Srinivas ${ }^{2}$ and Roman Tandlich ${ }^{3}$ \\ 'Environmental and Biotechnology Research Unit, Division of Pharmaceutical Chemistry, Faculty of Pharmacy, Rhodes University, PO Box 94, \\ Grahamstown 6140, South Africa \\ ${ }^{2}$ Division of Pharmacy Practice, Faculty of Pharmacy, Rhodes University, PO Box 94, Grahamstown 6140, South Africa \\ ${ }^{3}$ Division of Pharmaceutical Chemistry, Faculty of Pharmacy, Rhodes University, PO Box 94, Grahamstown 6140, South Africa
}

\begin{abstract}
Microbial water quality is an essential aspect in the provision of potable water for domestic use. The provision of adequate amounts of safe water for domestic purposes has become difficult for most municipalities mandated to do so in Zimbabwe. Morton-Jaffray Treatment Plant supplies potable water to Harare City and areas surrounding Harare. This study investigated microbial water quality and the impact of microbial water quality related disasters in the area supplied by the Morton Jaffray Treatment Plant. Questionnaires were distributed to household owners in Harare who receive their water from the Municipality and those who use alternate water supplies. Candidates were randomly selected from their workplace. The raw water quality of Manyame River and its tributaries was assessed. Treated water in households was assessed for microbial quality using hydrogen sulphide test and heterotrophic bacteria plate count. Raw water sources were found to be contaminated by faecal matter. Household water sources tested negative for faecal contamination but positive for heterotrophic bacteria. CFU quantities ranged from 1 to $452 \mathrm{CFU} / \mathrm{m} \ell$ for all samples. The WHO guidelines for domestic water sources state that water used for domestic purposes should not be contain than $100 \mathrm{CFU} / \mathrm{m} \ell$. Public perceptions of water quality ranged from 'unsafe' to 'highly contaminated'. A decrease in the level of aesthetic appeal resulted in residents resorting to alternative sources such as wells and rivers for their domestic water. The current state of treated water was suitable for domestic use. Pathogen monitoring of domestic water is recommended using the hydrogen sulphide test and R2A agar test.
\end{abstract}

Keywords: microbial water quality, faecal contamination, $\mathrm{H}_{2} \mathrm{~S}$ strip test, $\mathrm{R} 2 \mathrm{~A}$ agar test

\section{INTRODUCTION}

Water is an indispensable human requirement which is critical for development (WHO, 2012; WHO/UNICEF, 2014). The human right to water entitles everyone to sufficient, safe, acceptable and physically accessible and affordable water for personal and domestic use (OHCHR, 2015; WHO, 2015). Safe drinking water is that which is free from micro-organisms, chemical substances and radiological hazards that constitute a threat to a person's health (UN, 2015). The quantity must suffice to meet basic human needs in terms of drinking, bathing, cleaning, cooking and sanitation; the World Health Organisation (WHO) sets this volume at approximately $50-100 \ell$ per person (WHO, 2015). The required minimum quality of household water is dependent on its specific use: drinking water must be safe for consumption whereas lower standards may be set for water for sanitation (Gleick, 1999; UN, 2015). The WHO provides guidelines which are then used to set national guidelines with standards for drinking water which suit each country (WHO, 2015). To be termed acceptable, water should be appealing in terms of colour, smell and taste to each individual using it for domestic purposes (UN, 2015). Referring once more to the WHO guidelines, a water source has to be within $1000 \mathrm{~m}$ of a household and collection time should not exceed $30 \mathrm{~min}$ from such a source. In order for water to be affordable to all, the United Nations Development Programme

\footnotetext{
* To whom all correspondence should be addressed. $\overline{\mathbf{\Xi}}+263773815$ 650; e-mail: tgchirenda@gmail.com Received: 15 July 2014; accepted in revised form 15 September 2015
}

(UNDP) suggests that water costs should not exceed $3 \%$ of the household income (OHCHR, 2015).

States are required by the WHO to ensure everyone's access to a sufficient amount of safe drinking water for personal and domestic uses. They are also obliged to progressively ensure access to adequate sanitation as a fundamental element for human dignity and privacy, and also to protect the quality of drinking water supplies and resources (UN factsheet number 35). The obligation to ensure access to safe drinking water for domestic purposes has also been addressed by the Millennium Development Goals. Millennium Development Goal (MDG) 7c aimed to halve the world population without sustainable access to safe drinking water and basic sanitation by 2015 (WHO, 2012; UN, 2013). This target was met 5 years ahead of schedule, as follows (UNDP, 2015): Between 1990 and 2012, 2.3 billion people gained access to improved drinking water sources (UNDP, 2015). Over a quarter of the world's population has gained access to improved sanitation since 1990; however, 48 million people still remained without access to an improved source of drinking water (UNDP, 2015). The Joint Monitoring Program (JMP) for Water Supply and Sanitation of WHO/UNICEF cautioned that achievement of this goal did not also take into account the quality of the water as well as reflect microbial safety or sanitary status (WHO, 2014; WHO/ UNICEF, 2012; Bain et al., 2014). Since MDG Target 7 focuses on ensuring environmental sustainability and Target $7 \mathrm{c}$ aims at ensuring access to improved drinking water sources and basic sanitation, meeting half the target of providing improved drinking water may be mistakenly thought to imply that the basic sanitation needs and microbial safety requirements were also met at the same time. The JMP for Water Supply and Sanitation categorizes a drinking-water source 
type as improved if, by nature of its construction or through active intervention, it is protected from outside contamination, in particular from contamination with faecal matter (WHO/ UNICEF, 2013). Improved source types include piped water into dwellings, yards or plots, standpipes, boreholes, and protected dug wells or spring water and rainwater (Bain et al., 2014). Substantial differences are observed in the presence and levels of contamination between countries, between urban and rural regions, and between water source types (Bain et al., 2012). These differences occur due to the varying distribution of bacterial and viral pathogens that cause diseases (Bain et al., 2012).

\section{Legal framework}

In Zimbabwe there are many legal frameworks that regulate water quality. These include the Water Act (Chapter 20:22), the Water Regulations (waste and effluent disposal) (S.I 274/2000), the Public Health Act (Chapter 15:09) and the Environmental Management Act (Chapter 20:27). In addition to these, there are also by-laws passed by the local authorities. These laws prescribe administrative measures for ensuring compliance with water quality standards, such as investigating and monitoring water pollution and issuing effluent discharge permits, and provide a legal compliance and enforcement structure (Mtisis, 2008).

\section{Microbial water quality and disease mapping in Zimbabwe}

Zimbabwe has experienced several cholera outbreaks since the early 1970s, occurring in 5-10 year cycles. Since 1998, cholera has been an annual occurrence with cases being reported in both rural and urban areas (UNDP, 2015). Previous outbreaks were relatively quickly contained by emergency approaches supported by a sound health delivery system. The past few years have seen the outbreaks of typhoid and cholera affecting a significant part of the population in Zimbabwe with less efficient response systems available to eliminate the threat. According to a study published by Manzungu and Chioreso (2012) for Zimbabwe, the Harare City Health Department revealed that the proportion of water samples that failed to meet World Health Organisation (WHO) standards rose from about $8 \%$ in 2001 to about $20 \%$ by 2005 in Harare. The incidence of water-related diseases, which often manifest as diarrhoea, increased as a consequence (Manzungu and Chioreso, 2012; Manzungu and Mabiza, 2004). Weekly diarrhoea cases rose from 200 in 2004 to about 800 in 2008 (Manzungu and Chioreso, 2012). The number of cases was said to be higher in the low-income suburbs than in the high-income suburbs because high-income households could afford alternative water sources (Manzungu and Chioreso, 2012; Manzungu and Mabiza, 2004). In order to assist in the containment of the 2008 epidemic, the UN recommended the use of treated municipal water for domestic purposes and urgently supplied treatment chemicals to the Morton-Jaffray Water Treatment Plant (WASH Atlas Zimbabwe, 2008-9). The United Nations also facilitated the provision of an alternative water supply to affected communities (WASH Atlas Zimbabwe, 20089). Between February and May 2010, Zimbabwe experienced typhoid outbreaks all over the country. There were 448 cases and 8 deaths reported from typhoid disease, mainly from Mabvuku and Tafara, two of Harare's high-density suburbs (WHO, 2015). In early November 2011, 30 to 50 new cases were being reported daily and the total case count surpassed 1500 by February 2012 (Kasolo et al., 2013). The outbreak was traced back to chicken and fish sold by street vendors in open-air markets which were contaminated by Salmonella typhii (Kasolo et al., 2013). The Ministry of Health and Child Welfare reported another typhoid outbreak in August 2014 which killed 9 people while 370 new cases were reported in Harare, Mutare and Chegutu (Reliefweb, 2015). All these cases were also purported to have arisen from poor sanitation and water supply services, especially in the highdensity suburbs of Zimbabwe (Kasolo et al., 2013). Kadoma City has had recurrent problems with watery diarrhoeal outbreaks since 2002. The following data were obtained from a study done in Kadoma from 2007-2011 by Maponga et al. (2013): In 2007, a rotavirus outbreak killed 34 children. The cholera outbreak in 2008 and 2009 affected 6000 people, with 127 deaths recorded. August 2008 to June 2009 saw a total of 98592 reported cases of cholera and 4288 deaths (UNDP, 2015). This was as a result of poor water and sanitation provision particularly in the rural areas but also in urban areas (UNDP, 2015). Another cholera outbreak in 2010 affected 123 people and caused 4 deaths in Kadoma City. A total of 1091 cases of watery diarrhoea were attended to between September and November 2011. Of these, 994 (91\%) were residents of Kadoma City and 552 cases (51\%) were female; 693 (64\%) cases were children less than 5 years old. The incidence rate of diarrhoea among children less than 5 years old was 548 per 10000 people, whilst for the children above 5 years old the incidence rate was 50 per 10000 people. The causative organisms that were isolated (Rotavirus, Salmonella spp., Shigella spp. and Escherichia coli) fit into the average incubation period of 3 to 5 days, which fits the profile of faecal contamination (Maponga et al., 2013). In 2014, a total of 328 people across the country died from diarrhoea linked to the consumption of contaminated tap water (The Sunday Mail, 2014). There were 55 deaths and 34 967 cases of common diarrhoea recorded in January alone (The Sunday Mail, 2014).

Most of the Zimbabwean urban population has been without running water for over 5 years and has only recently been re-included in the water reticulation systems (Health Matters, 2011). WHO statistics indicate that in $1990,71 \%$ of the rural population and $100 \%$ of the urban population had access to improved drinking water sources in Zimbabwe, compared to $69 \%$ rural and $97 \%$ of the urban population in 2011 (WHO, 2013). This change was not too significant from a statistical point of view but it shows that the Water and Sanitation Health programmes did not increase at the same rate as population margins. As the population grew, access to safe and adequate quantities of water reduced, while access to proper sanitation also decreased. Most of the problems, such as shortage of water, and recurrent sewer blockages, have not found permanent solutions, due to a lack of financial resources (Maponga et al., 2013).

The city of Harare is the capital of Zimbabwe. Deterioration in the microbial quality of water in the capital indicates the existence of the same problem in other cities and towns in Zimbabwe, since more resources are available to the development of the capital than the peri-urban and rural areas. Poor microbial water quality leads to waterborne disease outbreaks and the sooner this is identified, the faster it can be controlled. This research was, therefore, necessary to establish ways of assisting in determining the microbial potable-water quality situation in Harare. Once this was established, it then became necessary to determine ways of ensuring this analysis to be a sustainable process, gathering data from the stakeholders involved in this assessment and presenting results from analyses done. The results could be used to assess the microbial water quality of municipal water and alternative water sources to ensure access to safe water sources. 


\section{Description of study area}

Harare is located $1500 \mathrm{~m}$ amsl, and has a population of 2.1 million people and a land area of $872 \mathrm{~km}^{2}$ (Census, 2012). The water supply infrastructure has $6000 \mathrm{~km}$ of water pipes. Of this length, $200 \mathrm{~km}$ of iron pipes have so far been replaced with polyvinyl chloride (PVC) pipes. The city's water supply infrastructure was originally designed to supply 350000 people and has been progressively upgraded to supply 1.5 million people (Census, 2012). The current population expected to benefit from this infrastructure is approximately 4.5 million people, three times more than its current capacity (Census, 2012). Over the years, maintenance of the pipelines and the treatment plant were given priority over a complete upgrade of the water supply infrastructure. The projected water demand of $1400000 \mathrm{~m}^{3} / \mathrm{d}$ for 2015 is much more than the combined capacity of Lake Chivero and Manyame, which has a combined storage capacity of $727417000 \mathrm{~m}^{3}$ (Nhapi, 2009). The pipes used are asbestos cement (AC) and a steel type. The AC type is vulnerable to breakage due to ground movement, both during and after the rainy season, as well as due to soil expansion and contraction (Nhapi, 2009). The steel pipes corrode with age resulting in an increased leakage rate and burst frequency (Nhapi, 2009).

\section{Sewage treatment}

Samples collected were from the lower Manyame Catchment area, starting at Beatrice, to the treatment plant itself in the Bulawayo road. After the rains experienced from November to March, the water hyacinth was washed away down the river and the sewage washed further downstream. Heterotrophic bacteria require carbon to grow and, due to this extensive distribution of vegetation along the river bank, as well as the water hyacinth, a significant amount of heterotrophic bacteria would be expected in the samples collected from this river. The disposal of sewage waste is another major problem in the country. The Chitungwiza area, which receives its water from MortonJaffray Water Treatment Plant, has also been affected by sewage disposal problems. In response to this, the Government of Japan assisted the Chitungwiza Municipality through building of the Chitungwiza City Sewerage Treatment Improvement Project (Japan ODA, 2013). This helped to reduce the disposal of untreated sewage into the Manyame River's tributaries.

\section{METHODS}

The ability to process potable water for supply to the Manyame Catchment area was assessed through water quality monitoring along the water distribution system, from the main river sources, namely, Manyame River, Mupfure River and Mutsige River, to the households, namely, those of Norton and Harare (Queensdale, Msasa Park, Westgate and the central business district). Microbial water quality was assessed using the $\mathrm{H}_{2} \mathrm{~S}$ test according to Venkobachar et al. (1994) and Sobsey and Pfaender (2002) as modified by Luyt et al. (2011) and heterotrophic bacteria plate count using R2A agar from SigmaAldrich (Johannesburg, South Africa). The $\mathrm{H}_{2} \mathrm{~S}$ strip test can detect the presence/absence of faecal contamination in drinking water (Luyt et al., 2011). It has been used in microbial water quality monitoring in isolated areas with limited infrastructure and personnel availability, as assessed by Luyt et al. (2011). The heterotrophic bacteria plate count is used to quantify microbes found if the strip test reports positive for faecal contamination.

\section{Water sampling}

The samples were collected between January and November 2013. The dates selected for sampling were between the $9^{\text {th }}$ and $11^{\text {th }}$ of each month in order to maintain consistency. Sampling was done between 9:00 and 14:00 on either Friday or Saturday, depending on the distance between the various locations. Samples were delivered to the plating site in a portable ice chest. Table 1 shows the specific dates for the sampling procedure and the locations which were tested.

\section{$\mathrm{H}_{2} \mathrm{~S}$ test strips}

The $\mathrm{H}_{2} \mathrm{~S}$ test strip medium of Venkobachar et al. (1984) was modified using deoxycholate $(0.5 \% \mathrm{w} / \mathrm{v})$ to decrease the frequency of false positive results (Luyt et al., 2011). All chemicals were purchased from Sigma Aldrich (Johannesburg, South Africa). Additional equipment in the form of $100 \mathrm{ml}$ collecting bottles was purchased from Proplastics Pvt Ltd (Harare, Zimbabwe). The $\mathrm{H}_{2} \mathrm{~S}$ test strips were prepared as described by Luyt et al. (2011). Urine jars were placed in the Panasonic carbon dioxide incubator from Panasonic Biomedical Sales $\mathrm{UK}$ and heated at $54^{\circ} \mathrm{C}$ for over $16 \mathrm{~h}$, which was sufficient to provide sterile $\mathrm{H}_{2} \mathrm{~S}$ strip test kits. Thereafter the sampling kits were assembled and stored away from direct sunlight, at room temperature until required for use.

\section{R2A plates}

A digital LCD electronic scale (Quintet Industries Limited, Hong Kong) was used to measure accurately a mass of $20 \mathrm{~g}$ of $\mathrm{R} 2 \mathrm{~A}$ agar required to make a solution with $1.1 \ell$ of distilled water. This powder was then suspended into the water, and boiled in a pressure cooker to dissolve the medium completely. Previously boiled water was used to dissolve this medium faster and a time of 20-25 min was found to be ideal for this process. Soon after cooling the pressure cooker, it was opened and an adequate amount of hot agar poured into each Petri dish near an open flame to avoid contamination. These test medium were then left to cool and used to plate samples within $24 \mathrm{~h}$. Sterile controls were included and no growth was observed on the sterile and un-inoculated plates.

\section{Household level}

The external portion of the tap in the particular household was chemically sterilised using $70 \%$ ethanol. It was then opened and allowed to run for $10-15 \mathrm{~s}$. The sampling kit was then opened and filled with $20 \mathrm{~m} \ell$ of tap water. One $20 \mathrm{~m} \ell$ volume for the $\mathrm{H}_{2} \mathrm{~S}$ sampling kit and one sterile $100 \mathrm{~m} \ell$ bottle were collected per household. The samples were then stored on ice during

\begin{tabular}{|l|l|l|}
\hline \multicolumn{3}{|c|}{ TABLE 1 } \\
Sampling locations and times \\
\hline Day & Location & Time \\
\hline 11 January 2013 & Queensdale 1 & $09: 00-09: 20$ \\
12 January 2013 & Westgate & $13: 30-14: 00$ \\
10 May 2013 & Queensdale 2 & $10: 00-10: 30$ \\
11 May 2013 & Manyame River & $09: 00-09: 30$ \\
9 August 2013 & Msasa Park & $11: 00-11: 30$ \\
10 August 2013 & Mupfure River & $10: 30-11: 00$ \\
9 November 2013 & Samora Machel & $12: 00-12: 30$ \\
10 November 2013 & Mutsige River & $11: 30-12.00$ \\
\hline
\end{tabular}


transport from the sources to the testing site. All $\mathrm{H}_{2} \mathrm{~S}$ samples collected were stored in a dark box at room temperature for $72 \mathrm{~h}$ while checking at 24 -h intervals for a colour change from brown to black. The water sample collected in a sterile bottle was then used to assess for heterotrophic bacteria using the spread-plating technique. Samples were collected from households in Queensdale, Norton, the CBD (Samora Machel Avenue), Westgate and Msasa Park areas. All of these areas are supplied by water from the Morton-Jaffray Treatment Plant.

\section{Source level}

Samples were collected from the main river that supplies Morton-Jaffray Treatment Plant, i.e., Manyame River as well as its tributaries. Samples were collected from the lower Manyame Catchment area, starting at Beatrice, to the treatment plant itself, located on the Bulawayo road near Norton. Water hyacinth and sewage were observed in the river water when samples were being collected. However, after the rains experienced from November to March, the water hyacinth was washed away down the river and the sewage washed further downstream. Clear waters were observed from the Manyame River bridge stretching for at least $100 \mathrm{~m}$ east and west, where the water hyacinth used to be. Travelling downstream, the water hyacinth was found lodged within rocks on the river banks and some of it still floated in the river.

Because of the significant likelihood of contamination in the raw water source, single $100 \mathrm{~m} \ell$ sampling containers were collected to test for heterotrophic bacteria as well as faecal contamination. Fifteen $100 \mathrm{~m} \ell$ sampling bottles were bought from Proplastics (Harare, Zimbabwe) and cleaned using boiled water. They were then chemically sterilised in $1 \%$ sodium hypochlorite and $16 \%$ sodium chloride solution for $30 \mathrm{~min}$ and left to dry at room temperature until required for use. Nitril gloves were worn onsite. The bottles were then opened near running water to collect enough water to fill the bottles, and then closed immediately. At the testing site, $20 \mathrm{~m} \ell$ of water was then poured into the $\mathrm{H}_{2} \mathrm{~S}$ test kit for faecal contamination assessment. The samples were left to stand in a dark box at room temperature for $72 \mathrm{~h}$ and checked every $24 \mathrm{~h}$ for colour change from brown to black. This colour change represents a positive result for faecal contamination. The remainder was used for heterotrophic bacteria plate count.

\section{Heterotrophic bacteria plate count}

Sterile syringes of volume $10 \mathrm{~m} \ell$ (Merck Pty. Ltd.

(Johannesburg, South Africa) were used to collect $1 \mathrm{m \ell}$ samples from each of the sampling kits collected at both households and raw water sources. A single syringe was used to collect two 1 $\mathrm{m} \ell$ samples from the kit and inoculate two separate Petri dishes filled with R2A agar. The $1 \mathrm{~m} \ell$ samples were then spread-plated onto the agar, labelled, and left to stand at room temperature for $72 \mathrm{~h}$. Each syringe was used for plating two Petri dishes from the same sampling bottle and discarded after use. Results were reported as $\mathrm{CFU} / \mathrm{m} \ell$.

\section{Questionnaires}

Qualitative data on respondents' perceptions of water quality were analysed from the data obtained using questionnaires administered to the public. Open-ended questions were designed to limit these results to usable data. The pie chart in Fig. 3 shows how subjects responded to these questions. Information supplied additionally on the questionnaires was reported in the results. A total of 120 questionnaires were distributed for this study. Participants were selected randomly in their workplaces around the Harare CBD. Due to the diversity of the workplaces, most of the suburbs in Harare were well represented, with participants originating from high-, mediumand low-density areas responding. Consent forms were provided for participants and the questionnaires were written in English and Shona to accommodate everyone involved. Some participants were interested in contributing to the study but did not have time to complete questionnaires. These participants then provided their responses in the form of a group discussion. These discussions tackled the questions regarding the aesthetic appeal of their potable water and the frequency with which water cuts were experienced in their households.

\section{Interviews}

The first interview was carried out with Mr Freddy Chinyavanhu of the GA Laboratory. He provided insight on how water quality is tested at their laboratories. He also discussed the limitations that have been encountered in the assessment of water quality at national level and how external input may improve water quality testing services. The second interview was conducted with the Drug and Toxicology Information Services personnel. They explained how they have been holding workshops to assist the community in handling general poisoning cases. They also held workshops with hospital staff at Corporate 24 and Parirenyatwa Hospitals to better equip them to deal with poisoning cases, including those that present with diarrhoea, which may then be confused with gastro-enteric disease. The third interview was conducted with the City of Harare Quality Assurance Office laboratory technicians. They explained the purification process that water undergoes before being supplied to the general public. They also provided insight on the laboratory tests performed in Quality Assurance to ensure the safety of the end users of water from the MortonJaffray Treatment Plant and the limitations they encountered in water quality testing and service delivery. Their names were however withheld for privacy purposes. Interviews with other members of staff alerted me to the upgrades to the pipeline system, whereby old rusty pipes were being replaced with new PVC type pipes. The old pipes are shown in Fig. 1 on the next page.

\section{RESULTS}

The following results were obtained from the study. Samples obtained from the CBD and in the Westgate area had limited microbial growth. All river samples had elevated concentrations of the R2A heterotrophic bacteria plate count (HPC) with actual values ranging from 225 to $452 \mathrm{CFU} / \mathrm{ml}$. These results indicated that the consumption of the sampled surface water without treatment would result in a medium public health risk of a waterborne disease outbreak. Water treatment prior to human consumption is thus required and there is room for improvement in the microbial water quality, i.e., after this water is treated at the Morton-Jaffray Treatment Plant. River samples were also found to be positive for faecal contamination based on the qualitative signals in the improved $\mathrm{H}_{2} \mathrm{~S}$ test kit, which also indicates that this water is not recommended for domestic purposes. Households recorded CFU/m $\ell$ counts of 
1 to 7 . This is within the range of the recommended $100 \mathrm{CFU} /$ $\mathrm{m} \ell$ for drinking water use. Sampling done at the household level showed microbial growth, although to a lower extent than in river water. The water samples collected did not have visible floating particles in them. There was also no significant odour in the treated water samples upon collection. This indicates that the level of precipitable components of potable water likely achieved the required standard.

Samples from Norton were found to have no faecal contamination and a heterotrophic bacteria plate count of $2 \mathrm{CFU} /$ $\mathrm{m} \ell$, i.e., the risk to public health from the water consumption is negligible. This may have resulted from an improvement in the quality of the pipe network after replacement of old iron pipes with PVC ones.

\section{Questionnaires}

A total of 120 questionnaires were distributed in the Harare Central Business District (CBD) area. 115 of these questionnaires were returned after being completed fully. Sixty-five (65) of these questionnaires were completed by tap-water users while 40 were completed by borehole-water users. Tables 2 and 3 represent the results obtained from the questionnaires.

Some interviewees reported that, after letting the water sit for a while, the green suspended particles settled at the bottom of the containers and they were able to decant the sedimentfree supernatant into another container. Those interviewees who reported rusty-coloured water said that it had a metallic taste and that they boiled it before use. However, after boiling the water in a pot, a cream to brown precipitate formed which settled to the bottom of the pot and which they then removed by filtering the boiled water through a clean cloth. In other studies, a brown colour was found in the water which can be indicative of rusting in the pipes (Keyser, 1997). A metallic taste also shows the presence of iron or manganese in the pipes (Keyser, 1997). Green particles in water indicate the presence of copper precipitates (Keyser, 1997). Cloudy water is indicative of organic or inorganic particles suspended in water which cause turbidity (Keyser, 1997). Further studies should include analysis of this municipal water for the presence and concentrations of heavy metals and the geographical distribution of their occurrences. In addition, other organic or inorganic material present in this water needs to be identified.

\section{R2A agar test findings}

These results provide an analysis of the heterotrophic bacteria results throughout the testing period from January to November 2013 (Table 4). The overall type of bacteria growing on R2A agar had a cream to dark brown colour. In samples
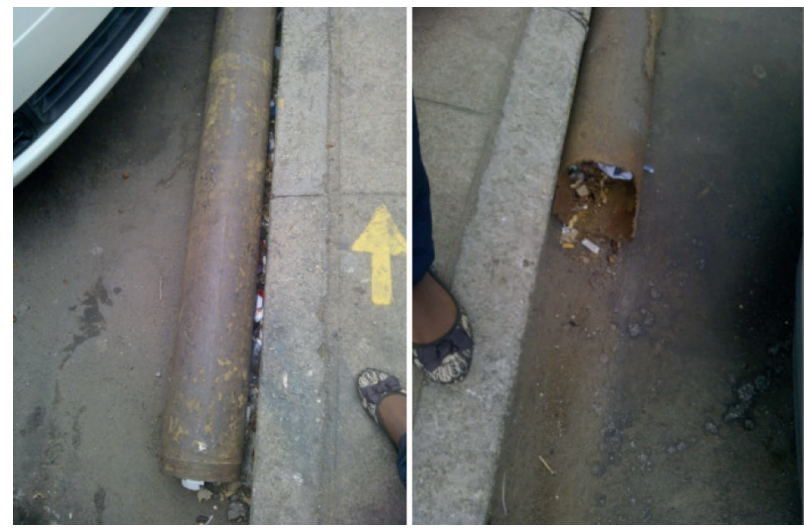

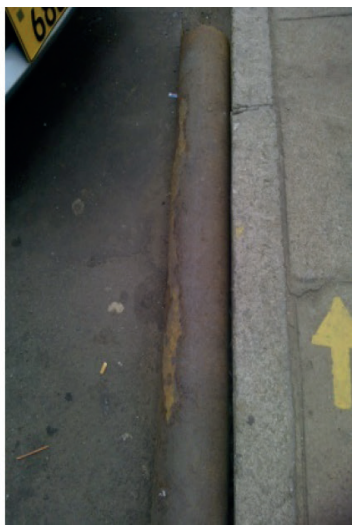

Figure 1

Rusty iron pipes removed from the distribution chain in the CBD

TABLE 2

Responses provided to questionnaires by tap water users

\begin{tabular}{|c|c|}
\hline QUESTION & ANSWERS \\
\hline $\begin{array}{l}\text { Access to clean potable water at } \\
\text { their household? }\end{array}$ & $\begin{array}{l}75 \% \text { yes } \\
25 \% \text { no }\end{array}$ \\
\hline $\begin{array}{l}\text { How often they experience water } \\
\text { cuts? }\end{array}$ & $\begin{array}{l}55 \% \text { monthly } \\
25 \% \text { weekly } \\
20 \% \text { never }\end{array}$ \\
\hline $\begin{array}{l}\text { Are there times when water is } \\
\text { not appealing to drink? Brief } \\
\text { description of how it looks. }\end{array}$ & $\begin{array}{l}60 \% \text { yes: colourless with sus- } \\
\text { pended green particles. Other } \\
\text { times it foams with white } \\
\text { bubbles. } \\
40 \% \text { yes: brown suspension }\end{array}$ \\
\hline $\begin{array}{l}\text { Reports of pipe bursts recently } \\
\text { in the area? Were they repaired } \\
\text { since then? }\end{array}$ & $\begin{array}{l}\text { Yes : } 70 \% \text { reported } \\
30 \% \text { did not report }\end{array}$ \\
\hline $\begin{array}{l}\text { Outbreaks due to water-borne } \\
\text { diseases in the area recently and } \\
\text { when. }\end{array}$ & $\begin{array}{l}\text { Yes: } 18 \% \text { cholera, } 2008 \\
\text { Yes: } 10 \% \text { typhoid } 2011\end{array}$ \\
\hline
\end{tabular}

TABLE 3

Responses to questionnaires by water tank users

\begin{tabular}{|l|l|}
\hline QUESTIONS & ANSWERS \\
\hline $\begin{array}{l}\text { What is the water in the tank } \\
\text { used for and how often? }\end{array}$ & $\begin{array}{l}100 \% \text { domestic purposes and } \\
\text { every day }\end{array}$ \\
\hline $\begin{array}{l}\text { Chemical treatment of water? } \\
\text { With which chemicals? }\end{array}$ & $\begin{array}{l}\text { Borehole source, no treatment } \\
\text { Rainwater, no treatment } \\
\text { Tap water, Waterguard dilute } \\
\text { chlorine solution }\end{array}$ \\
\hline Do they boil water before use? & $\begin{array}{l}\text { Yes: tap water filling users } \\
\text { No: borehole and rainwater } \\
\text { harvesting tank owners }\end{array}$ \\
\hline Source of water supply for tanks? & $\begin{array}{l}\text { Rain } 50 \% \\
\text { Wells } 35 \% \\
\text { Tap water } 15 \%\end{array}$ \\
\hline
\end{tabular}


TABLE 4

Results of microbial water quality tests

\begin{tabular}{|c|c|c|c|c|c|c|c|c|}
\hline \multirow{2}{*}{$\begin{array}{l}\text { Location (GPS coordinates } \\
\text { given in brackets }\end{array}$} & \multicolumn{2}{|c|}{ JANUARY } & \multicolumn{2}{|c|}{ MAY } & \multicolumn{2}{|c|}{ AUGUST } & \multicolumn{2}{|c|}{ NOVEMBER } \\
\hline & $\mathrm{H}_{2} \mathrm{~S}$ & R2A & $\mathrm{H}_{2} \mathrm{~S}$ & R2A & $\mathrm{H}_{2} \mathrm{~S}$ & R2A & $\mathrm{H}_{2} \mathrm{~S}$ & R2A \\
\hline $\begin{array}{l}\text { Manyame River } \\
(-17.980877,30.962373)\end{array}$ & $+v e$ at $36 \mathrm{~h}$ & 394 & $\begin{array}{l}+ \text { ve at } \\
36 \mathrm{~h}\end{array}$ & 452 & $+v e$ at $24 \mathrm{~h}$ & 386 & $+\mathrm{ve}$ at $24 \mathrm{~h}$ & 420 \\
\hline $\begin{array}{l}\text { Mupfure River } \\
(-17.857129,31.088408)\end{array}$ & + ve at $72 \mathrm{~h}$ & 274 & $\begin{array}{l}+ \text { ve at } \\
72 \mathrm{~h}\end{array}$ & 360 & + ve at $24 \mathrm{~h}$ & 320 & $+\mathrm{ve}$ at $24 \mathrm{~h}$ & 290 \\
\hline $\begin{array}{l}\text { Mutsige River } \\
(-18.254817,30.864880)\end{array}$ & + ve at $72 \mathrm{~h}$ & 225 & $\begin{array}{l}+ \text { ve at } \\
36 \mathrm{~h}\end{array}$ & 280 & $+v e$ at $24 \mathrm{~h}$ & 260 & + ve at $24 \mathrm{~h}$ & 245 \\
\hline $\begin{array}{l}\text { Queensdale household } 1 \\
(-17.857129,31.088408)\end{array}$ & $-\mathrm{ve}$ & 1 & $-\mathrm{ve}$ & 7 & $-\mathrm{ve}$ & 2 & $-\mathrm{ve}$ & 2 \\
\hline $\begin{array}{l}\text { Queensdale household } 2 \\
(-17.857129,31.088408)\end{array}$ & $-\mathrm{ve}$ & 3 & $-\mathrm{ve}$ & 6 & $-\mathrm{ve}$ & 2 & $-\mathrm{ve}$ & 0 \\
\hline $\begin{array}{l}\text { Msasa Park } \\
(-17.863594,31.114810)\end{array}$ & - ve & & $-\mathrm{ve}$ & & -ve & & $-\mathrm{ve}$ & \\
\hline $\begin{array}{l}\text { Samora Machel Avenue } \\
(-17.823972,31.059056)\end{array}$ & $-\mathrm{ve}$ & 1 & $-\mathrm{ve}$ & 0 & $-\mathrm{ve}$ & 0 & $-\mathrm{ve}$ & 0 \\
\hline $\begin{array}{l}\text { Westgate, Harare } \\
(-17.764211,30.977170)\end{array}$ & $-\mathrm{ve}$ & 0 & $-\mathrm{ve}$ & 0 & $-\mathrm{ve}$ & 0 & $-\mathrm{ve}$ & 0 \\
\hline $\begin{array}{l}\text { Norton } \\
(-17.873334,30.765766)\end{array}$ & $-\mathrm{ve}$ & 2 & $-\mathrm{ve}$ & 2 & $-\mathrm{ve}$ & 1 & $-\mathrm{ve}$ & 1 \\
\hline
\end{tabular}

collected from households, the colonies presented with a cream to beige colour, i.e., samples from Samora Machel offices, Norton, Queensdale and Msasa Park. Samples collected from the rivers presented with bacterial overgrowth which initially appeared to be cream but turned to a darker brown after $48 \mathrm{~h}$. These colonies were spread out distinctly throughout the plate which allowed for easier counting.

WHO guidelines for domestic water use recommend that samples tested should be negative in the $\mathrm{H}_{2} \mathrm{~S}$ test and that a heterotrophic bacteria plate count of less than $100 \mathrm{CFU} / \mathrm{m} \ell$ should be obtained.

\section{$\mathrm{H}_{2} \mathrm{~S}$ test findings}

All of the samples collected from households were negative for faecal contamination. This result was as expected since water that is at the end-user point is supposed to have no microbial contamination. Samples collected from rivers showed affirmative results after $24 \mathrm{~h}$ for Manyame River, Mutsige River and Mupfure River from August and September samples. This may have been due to first rains of the season which result in surface runoff into rivers carrying with it any human and animal wastes accumulated over the dry season. In the months of January-May, microbial concentrations were recorded at their highest in all three rivers as this marks the end of the rainy season and the approach of winter. The results for both $\mathrm{H}_{2} \mathrm{~S}$ and $\mathrm{R} 2 \mathrm{~A}$ are as shown in the table.

\section{RECOMMENDATIONS AND CONCLUSIONS}

Data could not be obtained for comparative purposes at the Government Analytical Laboratory for the same period due to restriction of access to such information for external researchers. Data could also not be obtained from the Quality Assurance Division in the Harare Municipality for the same reasons. This was therefore a limitation to this study.
Provision of such data to the community may help in assuring them that, despite the physical appearance of their tap water supplies, these are nevertheless safe to use for domestic purposes. Aesthetic appeal is an essential component in quality assurance, but notifying the general public that standard guidelines are being met for microbial quality would ensure less resistance by the public to the use of Harare municipal water sources.

It was found in this study that the City of Harare

Municipality is unable to provide adequate quantities of clean, treated water to the entire municipal area on a daily basis. It is, however, able to supply limited quantities of treated water that meet the WHO guidelines for domestic water use in a few locations in the city. This means treatment of water at the plant was sufficient to reduce the microbial load in potable water that had been processed from the raw water supplied to Morton-Jaffray Treatment Plant by Manyame River. The microbial quality of water was found to be within acceptable limits in households, but above the acceptable limits in the raw water sources.

The Government Analytical Laboratory also has limited resources to facilitate periodic pathogen monitoring. Some independent stakeholders may however be willing to partake in such a project. This laboratory could therefore be used as a centre for purchasing home-testing kits for borehole water or rainwater for the public. Each water source may not necessarily have the same requirements for water quality testing and these variations may, therefore, be addressed in specifically designed kits. Analysis of heavy metals, organic and inorganic compounds in Harare water on a regular basis is therefore a necessary occurrence if the authorities are to ensure public health.

\section{REFERENCES}

BAIN R, CRONK R, WRIGHT J, YANG H, SLAYMAKER T and BARTRAM JK (2014) Faecal contamination of drinking-water in low- and middle-income countries: a systematic review and meta-analysis. URL: http://journals.plos.org/plosmedicine/ 
article?id=10.1371/journal.pmed.1001644 (Accessed 12 July 2013). BAIN RES, GUNDRY SW, WRIGHT JA, YANG H, PEDLEY S and BARTRAM JK (2012) Accounting for water quality in monitoring access to safe drinking-water as part of the Millennium Development Goals: Lessons from five countries. Bull. World Health Organ. 90 228-235A.

CHINYAVANHU F (2012) Personal communication, 20 September 2012. Mr. Freddy Chinyavanhu, Ministry of Health and Child Welfare, CODEX Contact Point, Harare, Zimbabwe.

GLEICK P (1999) The Human Right to Water. Water Polic. 1 (5) 487-503.

Japan ODA on Zimbabwe (2013) Chitungwiza City Sewerage Treatment improvement project. URL www.mofa.go.jp/policy/oda/ category/water/contribute/03;iisei/kyokyo/c_e4.html (Accessed 9 August 2013).

KASOLO F, YOTI Z, BAKYAITA N, GATURUKU P, KATZ R, FISCHER JE and PERRY HN (2013) IDSR as a Platform for Implementing IHR in African Countries. Biosecur. Bioterrorism: Biodefense Strat. Pract. Sci. 11 (3) 163-169.

KEYSER SL (1997) Colors and smells in drinking water. URL: http:// extoxnet.orst.edu/faqs/safedrink/colors.htm (Accessed $26 \mathrm{March}$ 2014).

LUYT CD, MULLER WJ and TANDLICH R (2011) Low cost tools for microbial quality assessment of drinking water in South Africa. HealthMed 5 (6) Supplement 1 1868-1877.

MANZUNGU E and CHIORESO R (2012) Internalising a crisis? Household level response to water scarcity in the City of Harare, Zimbabwe. J. Soc. Dev. Afr. 27 (1) 111-135.

MANZUNGU E and MABIZA C (2004) Status of water governance in urban areas in Zimbabwe: some preliminary observations from the city of Harare. Phys. Chem. Earth 29 1167-1172.

MAPONGA BA, CHIRUNDU D, GOMBE NT, TSHIMANGA M and TAKUNDWA L (2013) Risk factors for contracting watery diarrhoea in Kadoma City, Zimbabwe, 2011: a case control study. BMC Infect. Dis. 13 567. URL: http://www.biomedcentral.com/14712334/13/567 (Accessed 21 April 2014)

MTISIS S (2008) Promoting water quality laws enforcement and implementation in Zimbabwe's urban areas. In: Proc. Eighth International Conference on Environmental Compliance and Enforcement, Linking Concepts to Actions: Successful Strategies for Environmental Compliance and Enforcement, 5-11 April 2008, Cape Town, South Africa.

NHAPI I (2009) The water situation in Harare, Zimbabwe: A policy and management problem. Water Polic. 11 221-235.
RELIEFWEB (2015) Typhoid kills nine, 370 fresh cases reported. URL: http://reliefweb.int/report/zimbabwe/typhoid-kills-nine-370-freshcases-reported (Accessed 23 May 2014).

OHCHR (OFFICE OF THE UNITED NATIONS HIGH COMMISSIONER FOR HUMAN RIGHTS) (2015) The Right to Water. UN Factsheet Number 35. World Health Organization (WHO), the Office of the United Nations High Commissioner for Human Rights (OHCHR), the Centre on Housing Rights and Evictions (COHRE), Water Aid, and the Center for Economic and Social Rights (CESR). URL: http://www.ohchr. org/Documents/Publications/FactSheet35en.pdf (Accessed: 3 March 2015).

UNDP (2015) We can end poverty. Millennium Development Goals and beyond 2015. URL: http://www.un.org/millenniumgoals/environ.shtml (Accessed: 3 March 2015).

UNICEF/WHO (2014) Joint Monitoring Programme: Definitions and Methods. URL: http://www.wssinfo.org/definitions-methods/ (Accessed 28 August 2014).

UN (2013) UN Goal 7: Ensure Environmental Sustainability. URL: http://www.un.org/millenniumgoals/environ.shtml (Accessed 28 August 2014).

UN (2015) Water for life decade 2005-2015. The human right to water and sanitation. URL: http://www.un.org/waterforlifedecade/ human_right_to_water.shtml (Accessed 13 January 2015).

WASH ATLAS ZIMBABWE (2008-9) Intervention Mapping for Water, Sanitation and Hygiene (WASH) in Zimbabwe. Who is Doing What and Where? Volume 1 ( $5^{\text {th }}$ edn). UNICEF, Ministry of Water Resources, Development and Management, Harare.

WHO (1997) Guidelines for Drinking Water Quality: Surveillance and Control of Community Supplies. Volume 3 ( $2^{\text {nd }}$ edn). World Health Organisation, Geneva.

WHO (2004) Guidelines for Drinking Water Quality. Recommendations. Volume 1 ( $3^{\text {rd }}$ edn). World Health Organisation, Geneva.

WHO (2012) Cholera. URL: http://www.who.int/wer/2012/wer8731 32. pdf (Accessed 15 February 2015).

WHO (2015) Water and Sanitation Health (WaSH). Content of the human right to water. URL: http://www.who.int/water_sanitation_health/humanrights/en/index2.html (Accessed 4 March 2015)

WHO/UNICEF (2013) Progress on Sanitation and Drinking-Water: 2012 Update. World Health Organisation/United Nations Children's Fund, Geneva. URL: http://www.wssinfo.org/definitionsmethods (Accessed 28 August 2014). 